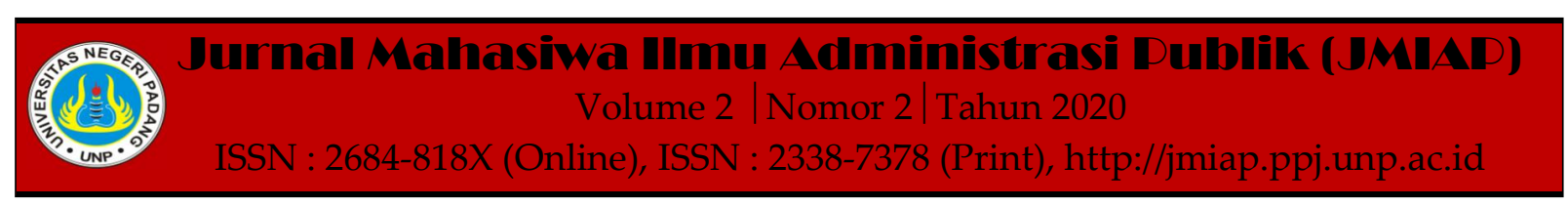

\title{
MANAJEMEN KONFLIK PENGADAAN TANAH PEMBANGUNAN JALAN TOL PADANG-SICINCIN
}

\author{
Miftah Urrahmi ${ }^{1(a)}$, Nora Eka Putri ${ }^{2(b)}$ \\ ${ }^{1}$ Jurusan Ilmu Administrasi Negara, Universitas Negeri Padang \\ ${ }^{2}$ Jurusan Ilmu Administrasi Negara, Universitas Negeri Padang \\ a)urrahmim@gmail.com, ${ }^{b}$ noraekaputri@fis.unp.ac.id
}

\begin{abstract}
This research aims to examine the conflict management of land acquisition for the construction of the Padang-Sicincin toll road. The approach used is this research approach using a descriptive qualitative type approach that is gathering information from various sources and can be proven by facts and using documentation studies. From this research it can be seen that the PadangSicincin toll road conflict still occurs and is felt by various layers to the lower layers of the community. From the interview results it is known that the conflict management of land acquisition for the construction of the Padang-Sicincin toll road is not yet optimal and an in-depth study is needed. Conflict over toll road development is not only seen from land issues, but many impacts are caused by economic, social and environmental aspects.

Keywords : Conflict, Infrastructure, Conflict Management, Society

Corresponding author.Email.urrahmim@gmail.com,noraekaputri@fis.unp.ac.id

How to cite this article. Nurrahmi. M \& Putri, N. Eka. (2020). Manajemen Konflik Pengadaan Tanah Pembangunan Jalan Tol Padang-Sicincin. Jurnal Mahasiwa Ilmu Administrasi Publik (JMIAP) Jurusan Ilmu Administrasi Negara Fakultas Ilmu Sosial Universitas Negeri Padang, Volume 2 (2), Hal. 9-17. http://jmiap.ppj.unp.ac.id

ISSN : 2684-818X (Online), ISSN : 2338-7378 (Print)

Copyright $(2020$. Published by Pusat Kajian-Pemberdayaan dan Pelayanan Masyarakat (PK-P2M) FIS UNP Padang
\end{abstract}




\section{PENDAHULUAN}

Semakin bertambahnya pertumbuhan penduduk, maka bertambah pula tingkat akan kebutuhan masyarakat, baik sandang, pangan, papan, kesehatan, transportasi, dan kesehatan.Transportasi merupakan hal yang sangat penting bagi manusia untuk beraktivitas dalam bepergian. Jalan adalah prasarana transportasi darat yang berada di permukaan tanah/air atau di atas permukaan air. Jalan tol adalah jalan yang digunakan oleh umum secara nasional yang penggunanya diwajbkan untuk membayar tol (Undang-Undang No 38, 2004). Jalan tol memiliki peran yang sangat penting bagi kelangsungan hidup masyarakat, juga jalan tol merupakan jalan bebas hambatan yang dibawahi langsung oleh Pemerintah Daerah yang nantinya akan menunjang perekonomian masyarakat sekitar lokasi jalan tol demi mewujudkan pembangunan dalam pengembangan wilayah.Proyek pembangunan jalan tol ruas PadangSicincin telah direncanakan sejak tahun 2017. Namun proses pembebasan lahan yang merupakan factor utama yang membuat mandeknya pembangunan jalan tol hingga saat ini belum diselesaikan. Ditambah lagi karena harga tanah yang ditakar oleh Tim Apprasisal terlalu kecil yang menimbulkan konflik antar Pemerintah dengan masyarakat yang terkena dampak akan tanahnya untuk pembangunan jalan tol. Awalnya, masyarakat yang tanahnya akan digunakan untuk pembangunan jalan tol tidak seluruhnya menyetujui dengan pembebasan lahan untuk pembangunan jalan tol PadangSicincin. Hingga saat ini tercatat $18 \%$ tahap konstruksi pada panjang 0-150 km. Manfaat jalan tol Sumbar-Riau akan meningkatkan perekonomian masyarakat khususnya masyarakat yang berprofesi sebagai pedagang. Mengingat sayuran hasil Sumbar banyak yang dikirim ke daerah Riau begitupun sebaliknya. Dengan adanya jalan tol ini maka pedagang tidak akan merasa rugi lagi akan harga penjualan yang cenderung rendah karena sayuran tersebut sudah berubah warna atau sudah layu.

\section{Tabel 1. Sesi Pembangunan Jalan Tol Sumatera Barat-Riau}

\begin{tabular}{lc}
\hline \multicolumn{1}{c}{ Sesi } & Pjg \\
\hline Sesi 1 Padang - Sicincin & $36 \mathrm{Km}$ \\
Sesi 2 Sicincin - Bukittinggi & $38 \mathrm{Km}$ \\
Sesi 3 Bukittinggi - & $34 \mathrm{Km}$ \\
$\begin{array}{l}\text { Payakumbuh } \\
\text { Sesi 4 Payakumbuh - }\end{array}$ & $58 \mathrm{Km}$ \\
Pangkalan & \\
Sesi 5 Pangkalan - Bangkinang & $56 \mathrm{Km}$ \\
Sesi 6 Bangkinang - Pekanbaru & $38 \mathrm{Km}$ \\
\hline \multicolumn{1}{c}{ Jumlah } & $\mathbf{2 6 0 ~ K m}$ \\
\hline
\end{tabular}

Pembangunan jalan tol ruas PadangSicincin ini dipertanggungjawabkan langusng oleh PT.Hutama Karya dan dibagi atas 2 tahap. Tahap pertama sudah terselesaikan dari tahap PPJT (Penandatanganan Perjanjian Pengusahaan Jalan Tol) sudah melakukan rapat serta disetujui langsung oleh mamak kepala waris yaitu Atrinaldi, dan berlanjut pada tahap konstruksi hingga panjang $150 \mathrm{~km}$. sedangkan pada tahap kedua dimulai dari panjang151 km hingga 4,2 km dan masih dalam tahap selesai PPJT, karena banyak masyarakat yang belum mendapatkan ganti ruginya. Penyebab ini menjadikan pembangunan jalan tol panjang 151-4,2 km belum pada proses konstruksi. Pada panjang 151-4,2 km ini sebagian pihak masyarakat telah menyetujui dengan penawaran harga yang ditentukan oleh pihak pengadaan tanah yang saat ini ditakar oleh Tim Appraissal. Tetapi sebagian pihak mempersulit proses pembebasan lahan dengan alasan harga yang ditakar terlalu kecil. Berdasarkan kutipan TribunPadang.com, trase yang awalnya akan dibangun pada daerah Sicincin dirubah kedaerah Kepala Hilalang Kecamatan Kayu Tanam Kabupaten Padang Pariaman, karena beberapa alasan yaitu masyarakat daerah Sicincin menolak tanahnya, harga tanah yang tidak sesuai, dan lahan tersebut merupakan lahan produktif dan panjang tol Padang-Sicincin juga berubah menjadi $36 \mathrm{~km}$. Dalam Komite Percepatan Penyediaan 
Infrastruktur Prioritas (KPPIP) tertera bahwa pembangunan jalan tol ruas PadangSicincin hingga Bukittinggi yang dipertanggungjawabkan oleh PT. Hutama Karya yang bernilai sebanyak Rp. 7.8 triliun itu direncanakan akan mulai beroperasi pada tahun 2019, akan tetapi hingga saat ini pada tahun 2020 baru mencapai $4,2 \mathrm{~km}$ proses konstruksi dari total panjang keseluruhan $36 \mathrm{~km}$.

Pelaksanaan rekonstruksi jalan tol ruas Padang-Sicincin terhambat hingga kini dikarenakan permasalahan pembebasan lahan yang belum kunjung usai dan menuai banyak konflik diantara penyebabnya adalah tanah yang digunakan untuk pembangunan adalah tanah ulayat, harga ganti rugi yang terlalu kecil yaitu sebesar Rp. $40.000 / \mathrm{m}$, pemberian ganti rugi yang belum selesai, dari jumlah keseluruhan yang terkena dampak sebanyak 48 orang, hingga kini 9 orang yang baru mendapatkan ganti rugi tersebut. Dalam pembangunan jalan tol Padang-Sicincin nantinya akan menimbulkan debu, getaran, dan alat berat yang lalu lalang dalam proses pengerjaan, ini menjadi salah satu alasan masyarakat tidak menyetujui pembangunan jalan tol dilakukan disana, dan masyarakat meminta kompensasi atas kerugian yang akan didapatkan ketika pembangunan itu dilaksanakan seperti memberikan pelayanan gratis untuk masuk jalan tol, atau memperkerjakan mereka pada pada proses pembangunan jalan tol. Akan tetapi, hingga proses konstruksi mencapai angka $18 \%$ tidak satu pun masyarakat terdampak yang dipanggil untuk bekerja disana. Kendala ini tentunya akan menimbulkan konflik antara masyarakat dengan pihak penyelenggara pembangunan jalan tol. Sulitnya menemukan solusi membuat Pemerintah berupaya mengganti uang ganti rugi masyarakat dengan cepat agar pembangunan dapat dilakukan. Lain halnya masyarakat yang masih tidak menyetujui dengan harga, mengajukan protes kepada Gubernur Sumatera Barat dengan harap agar Pemerintah dapat mempertimbangkan kembali harga tanah mereka. Namun hasil keputusan telah keluar dengan menetapkan harga tetap seperti semula. Masyarakat yang terdampak tidak dapat berbuat banyak. Berdasarkan wawancara dengan Bapak Seprizal selaku masyarakat yang terkena dampak, tanah saya yang terpakai seluas 1 hektar dan sampai saat ini tanah saya belum diganti, padahal kami disuruh untuk meminta ke Pengadilan, dan orang pengadilan pun menyuruh saya untuk menghadap pihak pengadaan tanah, setelah itu saya disuruh ke Pengadilan, dan sampai saat ini saya belum mendapatkan ganti rugi, sementara untuk mengurus dokumen ini itu tealh menghabiskan uang saya sebanyak 5 juta.

Konflik merupakan suatu perselisihan, perdebatan antara orang yang satu dengan yang lain terhadap isu, ide, dan gagasan. (Ekawarna, 2018) Konflik bermula dari ketidaksepadanan antara yang terjadi dengan apa yang diinginkan. Konflik juga berasal dari isu konflik itu sendiri, apakah positif maupun negative, kepribadian pribadi yang berkonflik, dan situasional. (Broadman dan Horowitz dalam (RICS, 2012). Sedangkan manajemen konflik merupakan proses antara yang terlibat konflik dalam menyusun strategi agar dapat menyelesaikan konflik. (Surata \& Andrianto, 2001). Dalam pembangunan jalan tol Padang-Sicincin sepanjang $36 \mathrm{~km}$ ini nantinya akan melewati 10 korong Nagari Kasang diantaranya Jambak, Tanjung, Chaniago, Guci, Sikumbang, Bintungan, Duku,Sei.Pinang, Kasai, dan Koto. Sedangkan lima korong yang terkena dampak dari pembangunan jalan tol ini yaitu Pinang, Bintungan, Chaniago, Koto, dan Kasai.

\section{TINJAUAN PUSTAKA \\ Konsep Manajemen}

Menurut Mary Parker Follet dalam (Kotler, 2015), manajemen adalah kegiatan seni dalam menyelesaikan pekerjaan dengan bantuan orang lain. Sedangkan menurut (Rausch, 1990), manajemen berarti aktivitas dalam menggabungkan koordinasi dan pengawasan dalam pekerjaan sehingga 
dapat terselesaikan dengan efektif dan efisien.

\section{Konsep Konflik}

Menurut Folger dalam (Ekawarna, 2018), konflik berarti komunikasi antar orang-orang yang saling berhubungan dan merasakan tujuan dan gangguan yang tidak cocok antara pihak satu dengan yang lainnya dalam mencapai tujuan. Menurut Bodtker et al dalam (Ekawarna, 2018), bentuk konflik dibedakan atas: sikap (attitude), perilaku (behaviour), kontradiksi (contradiction). Jenis konflik menurut (Ekawarna, 2018) terbagi atas konflik pribadi yaitu konflik yang terjadi antara dua orang yang berselisih paham, Konflik intrapersonal berarti konflik yang terjadi pada diri seseorang, Konflik peran terjadi ketika tiap individu harus memenuhi keharusan yang berlawanan dari dua orang atau lebih anggota organisasi, dan Konflik interpersonal terjadi ketika individu melakukan komunikasi untuk menghasikan tujuan.

Dampak positif dari konflik adalah konflik berguna untuk memperkuat hubungan antar individu didalam kelompok, dapat memotivasi anggota dalam organisasi untuk mengawasi tujuan terhadap organisasi. Sedangkan dampak negatif konflik adalah tanggapan psikologis, tanggapan perilaku, dan tanggapan fisik.

\section{Konsep Manajemen Konflik}

Menurut Minnery dalam (Ekawarna, 2018), manajemen konflik adalah proses untuk mengendalikan konflik tersebut. Sedangkan Ross at al mendefinisikan manajemen konflik berarti tahap-tahap yang dilakukan oleh pihak ketiga untuk mengarahkan perselisihan ke arah yang positif seperti ketenangan dan kedamaian. Tahap manajemen konflik menurut stevenin dalam (Muspawi, 2014) adalah pengenalan, diagnosis, menyepakati suatu solusi, pelaksanaan solusi dan evaluasi.

\section{METODE PENELITIAN}

Penelitian ini menggunakan deskriptif dengan menggunakan teori stevenin dalam (Muspawi, 2014) yang melihat dan memahami manajemen konflik pendekatan tersebut dapat diketahui melalui pengalaman yang disampaikan oleh subyek penelitian tentang pandangan masalah tersebut. Penyajian data menggunakan penelitian deskriptif dengan tujuan dapat mengumpulkan menganalisis,danmengeinterpretasikan agar bisa menjelaskan dan menggambarkan berbagai kondisi yang terjadi di tengah masyarakat, yang nantinya akan menjadi obyek penelitian, kemudian menarik kesimpulan dari sebuah pembahasan sebagai gambaran, situasi atau kondisi dari variable tersebut (Sugiyono, 2014). Penelitian ini akan berupaya menggali data memahami konflik yang terjadi pada masyarakat Nagari Kasang khususnya masyarakat yang terkena dampak dan sekitar lokasi pembangunan jalan tol Padang-Sicincin. Persepektif manajemen konflik tentang pembangunan jalan tol ini dan factor - factor yang mempengaruhi manajemen konflik itu sendiri.

Dalam teknik pengumpulan data yang digunakan peneliti berdasarkan pada dua bagian yaitu data primer dan sekunder. Data primer merupakan data yang bersumber dari responden secara langsung dengan melakukan observasi dan pengamatan terlebih dahulu terhadap situasi dan kondisi yang terjadi di lokasi penelitian. Observasi ini digunakan agar dapat mengetahui situasi dan keluhan yang benar-benar terjadi pada masyarakat sekitar lokasi pembangunan jalan tol. Sebelumnya, peneliti sudah melakukan wawancara dengan beberapa subyek penelitian yang sedang berkonflik dengan pihak pengadaan tanah. Wawancara digunakan agar pertanyaan yang nantinya akan diajukan bersifat lebih terbuka dengan merujuk pada pedoman wawancara dan akan lebih menghasilkan data yang lebih obyektif. Dari wawancara yang didapatkan di lapangan, selanjutnya akan dicatat di notebook, bertujuan untuk mengantisipasi 
jika ada hal-hal yang akan terlupa. Informasi yang didapatkan peneliti akan direkam dengan bantuan handpone selular dan nantinya akan disalin kembali pada notebook. Hal ini dilakukan agar tidak ada data ataupun informasi yang terlewatkan sehingga dapat menghasilkan tulisan yang valid nantinya. Pengumpulan data sekunder didapatkan dengan cara mencari berita terbaru, artikel, jurnal, serta UndangUndang mengenai permasalahan yang terkait. Dalam penelitian ini peneliti menggunakan pendekatan kualitatif. Informasi berisikan pengamatan dan hasil wawancara pada saat peneliti melakukan penelitian. Informasi ini mencerminkan pribadi peneliti dengan mengacu pada kerangka konseptual dan meinginterpretasikannya terhadap catatan deskriptif di lapangan. Kemudian hasil dari wawancara dan pengamatan ini akan dianalisis sehingga menjadikan data yang sempurna.

\section{HASIL DAN PEMBAHASAN}

Pembangunan jalan tol ruas PadangSicincin yang berlokasikan di Nagari Kasang Kabupaten Padang Pariaman mulai dilaksanakan pada tahun 2019 yang direncanakan akan dimulai pada tahun 2017. Namun banyak perubahan dan pertimbangan disebabkan perbedaan ide dan pikiran antara Pemerintah dengan masyarakat terhadap proyek yang jalan tol. Mandeknya pembangunan jalan tol ruas Padang-Sicincin disebabkan permasalahan pembebasan lahan yang membutuhkan waktu yang lama karena lahan yang berada di lokasi pembangunan adalah tanah ulayat yang dikepalai oleh 1 mamak ahli waris serta banyak anggota dalam satu sertifikat sehingga membutuhkan banyak persetujuan dari setiap anggota. Pada perencanaan pembangunan jalan tol Padang-Sicincin ini, masyarakat Nagari Kasang yang terkena dampak pembangunan jalan tol merasa "ditipu". Hal ini disebabkan adanya masyarakat yang setuju dan tidak setuju terhadap pembangunan jalan tol. Namun bagi masyarakat yang setuju hingga saat ini belum mendapatkan ganti rugi dari tanah mereka yang digunakan untuk pembangunan jalan tol.

Masyarakat yang tidak setuju dengan pembangunan jalan tol karena pihak pengadaan tanah bersama Tim Appraissal terlalu kecil dalam menakar harga tanah, yaitu sebesar Rp.42.000/m dan tanaman karet hanya ditakar sebesar Rp.25.000/batang.Tetapi, pihak Pemerintah maupun pihak pengadaan tanah berpikir upaya mereka sudah selesai sehingga pembangunan jalan tol Padang-Sicincin ini sudah mencapai diangka $18 \%$ hingga panjang $4,2 \mathrm{~km}$. namun masalah yang paling mendasar adalah Pemerintah harus menyelesaikan permasalahan pembebasan lahan dengan membayar ganti rugi kepada masyarakat dengan tindakan yang cepat. Karena jika tidak ditanggulangi, maka akan menimbulkan konflik baru kedepannya.

Oleh karena itu, solusi penting yang harus dilakukan Pemerintah adalah memasukkan pedoman dari UndangUndang Nomor 2 Tahun 2012 Tentang Pengadaan Tanah Bagi Pemabangunan untuk Kepentingan Umum. Substansi tersebut dijelaskan akan menjamin terselenggaranya pembangunan yang memprioritaskan prinsip adil, kemanusiaan, dan demokratis. Dengan demikian alur atau mekanisme dari pembangunan jalan tol ini tentunya tidak akan menuai banyak konflik.Pelaksanaan pengadaan tanah untuk pembangunan jalan tol Padang-Sicincin dibagi atas 4 tahap dimulai dari tahap perencanaan, tahap persiapan, tahap pelaksanaan dan terakhir tahap penyerahan hasil. (Perpres No 148 Tahun, 2015) Pada tahap pelaksanaan tertuang didalamnya adanya pemberian ganti rugi berupa uang, tanah pengganti, pemukiman, kepemilikan saham, dan bentuk lain.

Pembangunan Nasional tentunya untuk kepentingan umum akan melibatkan banyak pihak serta harus dilakukannya pemenuhan kebutuhan secara cepat. Pembangunan tidak hanya akan memberikan dampak positif bagi masyarakat, terkadang juga memberikan dampak negative yang dapat 
merugikan berbagai pihak. Dan pihak yang dirugikan adalah mereka yang merasa terjadinya kesenjangan sosial dan adanya ketidakadilan terhadap pembangunan jalan tol. Pembangunan jalan tol Padang-Sicincin menuai banyak konflik yang terjadi antara pihak pengadaan tanah dengan masyarakat Nagari Kasang yang terdampak dari pembangunan jalan tol. Masyarakat merasa pembangunan jalan tol belum sepenuhnya dibutuhkan di Provinsi Sumatera Barat. Pada dasarnya masyarakat tidak menyetujui pembangunan tol ini karena nantinya akan membuat masyarakat lebih sengsara lagi karena dampak dari masyarakat sekitar lokasi adalah akan terjadinya bencana alam seperti banjir yang diakibatkan oleh pembangunan jalan tol ini yang aka dibuat lebih tinggi dari pemukiman masyarakat, dan jalan berlubang disebabkan banyaknya mobil besar muatan berat yang hilir mudik untuk mengangkut material pembangunan jalan tol ini. Pun, dari awal masyarakat juga diberi iming-iming bahwa lahan masyarakat yang digunakan pembangunan jalan tol tidak akan rugi melainkan pihak Pemerintah akan ganti untung, tapi hingga saat ini ganti rugi belum dilakukan.

Penyelesaian masalah yang dilakukan Pemerintah dan pihak pengadaan tanah terhadap masayarakat yang kontra dengan pembangunan jalan tol Padang-Sicincin merasa dirugikan. Terdapat banyak alasan masyarakat yang muncul untuk menolak dilakukannya pembangunan jalan tol ataupun mereka tidak menyepakati harga pembebasan lahan. Padahal keputusan yang diberikan oleh pihak pengadaan tanah adalah keputusan langsung oleh Presiden, dan mereka hanya menuruti perintah.Masalah muncul disebabkan oleh perbedaan pendapat, situasi ketika terjadi bentrokan perihal peran seseorang dengan anggota lain, usaha dalam mencapai urusan pribadi, keterlibatan pihak ketiga dalam orientasi yang berbeda, sulit komunikasi dan interaksi, adanya tekanan dari luar. (Ekawarna, 2018).Menurut Stevenin dalam (Muspawi, 2014), menjelaskan untuk memanajemen konflik diperlukan beberapa tahap diantaranya pengenalan, diagnosis, menyepakati suatu solusi, pelaksanaan, dan evaluasi.

Pertama, proses pengenalan. Adanya perbedaan atau kesenjangan antara keinginan dengan kenyataan antara pihak yang berkonflik terhadap pembangunan jalan tol Padang-Sicincin. Pembangunan jalan tol ini akan menimbulkan banyak permasalahan dari masyarakat sekitar lokasi dan masyarakat yang terkena dampak terkait dengan proses pembebasan lahan yang sampai saat ini masih bermasalah pada panjang 4,2-36km. Pemerintah dan pihak pengadaan tanah yang terlibat menakar harga lahan masyarakat terlalu rendah yaitu sebesar Rp. 42.000/m dan tanaman karet hanya ditakar sebesar Rp. 25.000/batang. Menurut masyarakat harga ini terlalu rendah, karena menurut mereka harga tanaman karet mereka akan menghasilkan banyak jika dijual ke pasaran daripada dijual ke pihak pengadaan tanah pembangunan jalan tol. Lain halnya, rencana pembuatan trase pada daerah Sicincin berubah kearah Kepala Hilalang Kecamatan Kayu Tanam Kabupaaten Padang Pariaman dikarenakan masyarakat Sicincin tidak mau lahannya digunakan untuk pembangunan jalan tol karena mereka menjelaskan bahwa lahan yang akan digunakan itu merupakan lahan produktif. Disamping itu, tanah yang akan direncanakan untuk membuat trase adalah tanah ulayat, dan masyarakat menolak karena tidak sesuai dengan harga yang ditakar oleh pihak pengadaan tanah.

Kedua, diagnosis. Mengetahui penyebab dan factor-faktor terjadinya konflik agar dapat melakukan tindakan manajemen konflik. Pembangunan jalan tol ini menuai banyak konflik dari permasalahan pembebasan lahan, masyarakat terdampak yang setuju belum mendapatkan harga ganti rugi akan tetapi Pemerintah dan pihak pengadaan tanah tidak menindaklanjuti bahkan cenderung 'menutup telinga' dari semua itu dan pembangunan jalan tol tetap 
saja berjalan dan menyepelekan tanpa memperhatikan hambatan atau kendala yang terjadi. Terkait pembebasan lahan terhadap pembangunan jalan tol, Pemerintah Sumatera Barat pernah mengatakan bahwa pembangunan jalan tol tidak akan dilaksanakan jika belum selesainya permasalahan pembebasan lahan. Akan tetapi hingga kini pembangunan jalan tol Padang-Sicincin menginjak angka $18 \%$.

Ketiga, menyepakati suatu solusi. Dalam pembangunan jalan tol Padang-Sicincin ini masyarakat merasa 'tertindas dan malang'. Disatu sisi, Pemerintah sudah memberikan informasi akan memberikan harga ganti rugi dengan cepat kepada masyaraakat yang lahannya terkena dampak pembangunana jalan tol. Akan tetapi hingga saat ini dari 48 total keseluruhan masyarakat yang terkena dampak, baru 9 orang yang baru menerima ganti rugi dari Pengadilan.Ketika masyarakat yang lain meminta haknya dan mendatangi Pengadilan, lalu pihak Pengadilan menyerahkan massa kepada pihak pengadaan tanah, setelah itu kami menghubungi pihak pengadaan tanah dan kami dikembalikan lagi kepada Pengadilan. Masyarakat merasa 'dipermainkan' oleh Pemerintah dan pihak pengadaan tanah. Melihat peristiwa seperti ini, beberapa masyarakat memilih tetap bersabar hingga Pemerintah memberikan ganti rugi kepada mereka, tetapi beberapa masyarakat juga mencari upaya agar dapat mendapatkan hak mereka.

Keempat, pelaksanaan akan solusi yang sudah disepakati. Masyarakat yang terkena dampak pembangunan jalan tol PadangSicincin ini menyebabkan perekonomian mereka menjadi 'terancam', baik melalui ganti rugi maupun hasil dari tanaman mereka yang biasanya mereka hidup dari hasil tanaman mereka, kini tidak bisa karena lahan mereka sudah digarap untuk pembangunan jalan tol Padang-Sicincin, dan hingga saat ini ganti rugi tersebut belum mereka dapatkan. Konflik ini berawal dari rendahnya harga yang ditakar oleh Tim Appraisal, maka dari itu masyarakat tidak terima, terlebih lagi lahan masyarakat Nagari Kasang adalah tanah ulayat. Masalah tidak hanya sampai disana, masyarakat bertambah 'marah' ketika Pemerintah belum juga membayar harga ganti rugi tanah mereka. Solusi dari permasalahan ini adalah diharapkan Pemerintah segera membayar ganti rugi mereka agar tidak memunculkan konflik baru.Beberapa masyarakat membentuk sebuah kelompok agar harga tersebut bisa dipertimbangkan kembali. Dan hasilnya adalah masyarakat yang beranggotakan 6 orang itu kalah, dan Pengadilan mengatakan bahwa harga tersebut sudah berdasarkan ketentuan Pemerintah dan pihak pengadaan tanah.

Kelima, evaluasi dari solusi yang telah dilaksanakan. Masyarakat telah kalah dalam pidana yang mereka ajukan, berharap Pengadilan dapat mempertimbangkan usaha mereka terhadap harga tanah yang terlalu rendah. Pemerintah pun belum juga memberikan hak masyarakat. Menakutkan apabila masyarakat merencanakan hal lain terkait jalan tol kedepannya, karena penyebab mendasar konflik ini berawal dari Pemerintah itu sendiri. Berdasarkan penjelasan tahap manajemen konflik pembangunan jalan tol, maka focus permasalahan terletak pada permasalahan pembebasan lahan yaitu besar ganti rugi serta pemberian harga ganti rugi tersebut kepada masyarakat khususnya masyarakat Nagari Kasang yang terkena dampak pembangunan jalan tol Padang-Sicincin. Di satu pihak, pihak pengadaan tanah menakar harga sesuai dengan NJOP dan ketentuan dari Pemerintah, sedangkan disisi lain Pemerintah belum juga memberikan hak ganti rugi kepada masyarakat yang terdampak. Berdasarkan kejadian tersebut, wajar masyarakat melakukan perlawanan dengan Pemerintah ataupun pihak pengadaan tanah terkait pembangunan jalan tol. Dengan adanya pembangunan jalan tol ini, maka ada masyarakat yang menyetujui 
harga ganti rugi dan ada yang tidak menyetujuinya. Pada kenyataannya, pemberian ganti rugi terhadap lahan dan tanaman yang dijadikan lokasi pembangunan jalan tol belum sepenuhnya adil dalam pembagian.

Dengan melihat kondisi yang terjadi saat ini, masyarakat sudah menyetujui pembangunan jalan tol ruas PadangSicincin secara keseluruhan asal ganti rugi lahan yang digunakan diganti dengan cepat. Masyarakat berharap pihak Pemerintah dapat membicarakan dan menyelesaikan permasalahan dengan duduk bersama demi menuntaskan permasalahan dari pembangunan jalan tol ini. Peneliti berpendapat belum terlaksananya penerimaan ganti rugi menjadi hal mendasar yang menjadi penyebab konflik. Buktinya bahwa selama ini yang menjadi permasalahan terhadap pengadaan tanah adalah bukan lagi masyarakat yang tidak menyetujui harga yang ditakar, akan tetapi belum diberikannya harga ganti rugi oleh Pemerintah padahal tanah ini milik masyarakat, mereka menggarap, merawat, dan menjaganya dengan baik, ketika tanah mereka digunakan untuk pembangunan jalan tol, Pemerintah wajib membayar jerih payah mereka dengan membayar ganti rugi. Jalan keluar dari konflik ini satu-satunya adalah mendengarkan keluhan masyarakat dengan membayar ganti rugi sesuai dengan kesepakatan awal.

\section{PENUTUP}

Berdasarkan uraian yang sudah peneliti di atas, maka dapat disimpulkan bahwa manajemen konflik pengadaan tanah pembangunan jalan tol ruas PadangSicincin dilakukan dengan beberapa tahap. Tahap pertama yaitu pengenalan, pembangunan jalan tol pernah diberikan sosialisasi oleh Pemerintah Daerah kepada masyarakat akan tetapi masih belum maksimal. Tahap kedua adalah diagnosis, pembangunan jalan tol menyebabkan konflik dimana asal mulanya adalah harga tanah masyarakat ditakar terlalu rendah oleh Pemerintah, tanah ulayat, sertifikat ganda, dan masyarakat belum menerima ganti rugi akan lahan mereka. Tahap ketiga yaitu menyepakati solusi dimana solusi agar konflik dapat diselesaikan. Tahap keempat adalah pelaksanaan, solusi yang telah disepakati dan dilaksanakan. Dan tahap kelima adalah tahap evaluasi, setelah solusi dilaksanakan, konflik akan reda ataupun akan bertambah tergantung cara mereka mengimplementasikannya dan tahap ini digunakan agar tidak terjadi hal serupa dimasa mendatang, meskipun terjadi pihakpihak yang sudah mengetahui solusi ini dapat mengatasinya dengan cepat agar tidak berlarut-larut.

Akan tetapi penyebab utama adalah belum dilakukannya pemberian ganti rugi atas tanah masyarakat yang digunakan untuk pembangunan jalan tol. Dimulai dari panjang 0-150 yang sudah selesai dilakukan konstruksi, belum juga diberikan ganti rugi dan kini dilanjutkan dari panjang 150-4,2 $\mathrm{km}$ belum dibangun karena masih berkonflik karena masyarakat menolak pembangunan. Pembangunan jalan tol ini akan melahirkan dampak positif dan negative. Dampak positif adalah baik bagi para pedagang karena dapat meningkatkan harga jual sayuran yang akan mereka jual lagi ke pasar, ataupun bagi masyarakat yang bekerja di luar kota sehingga dapat menghemat waktu. Lain halnya dampak negative yang akan dirasakan oleh masyarakat adalah terjadinya penurunan perekonomian masyarakat yang awalnya mereka dapat berjualan di tepi jalan Sicincin kini tidak bisa lagi karena pembangunan ini, pemukiman masyarakat lokasi jalan tol yang juga akan terdampak baik bagi lahan mereka maupun jalan yang mereka gunakan sehari-hari. Adakalanya jalan tol tidak semua kendaraan dapat menggunakannya, melainkan hanya kendaraan roda 4 dan yang memiliki kapasitas cc yang tinggi yaitu lebih dari 1.500cc.Menurut masyarakat pembangunan jalan tol Padang-Sicincin akan membuat perekonomian masyarakat akan bertambah mati, dan mengenai rest area yang dijanjikan Pemerintah akan didirikan di titik 
sepanjang jalan tol masih hanya wacana Pemerintah yang menjadi iming-iming yang akan diutarakan kepada masyarakat agar pembangunan jalan tol ini disetujui oleh masyarakat secara keseluruhan.

Adapun saran dalam penelitian ini adalah manajemen konfik pengadaan tanah pembangunan jalan tol ruas PadangSicincin harus dilakukan secara bertahap dengan cara melakukan membangun hubungan yang baik antara masyarakat dan Pemerintah agar mereka merasa bahwa Pemerintah tidak pernah memberikan janji palsu kepada mereka sehingga kesalahpahaman dapat terjawab dan selanjutnya Pemerintah harus melunasi pembayaran ganti rugi terhadap lahan masyarakat yang digunakan untuk pembangunan jalan tol maka tentunya tahap ini akan menjadikan konflik jalan tol ini lambat laun akan mereda dan masyarakat dapat menjalani kehidupan mereka seperti biasanya.

\section{DAFTAR KEPUSTAKAAN}

Ekawarna. (2018). Manajemen Konflik dan Stres. Jakarta: Bumi Aksara.

Kotler. (2015). Pengantar Manajemen. 30.

Muspawi, M. (2014). Manajemen Konflik (Upaya Penyelesaian Konflik Dalam Organisasi). Jurnal Penelitian Universitas Jambi Seri Humaniora,
$16(2), 41-46$.

Perpres No 148 Tahun 2015. (2015). 151, $10-17$. https://doi.org/10.1145/3132847.3132 886

Rausch, D. O. (1990). Management and organization. In Surface Mining. https://doi.org/10.1201/b22034-6

RICS. (2012). 32954-IDFaktor Pemicu Konflik Pertanahan studi kasus Konlik Pertanahan. JOM FISIP, 3(1), 1-11. Retrieved from https://www.rics.org/southasia/upholding-professionalstandards/standards-of-conduct/ethics/

Sugiyono, P. D. (2014). Populasi dan sampel. Metode Penelitian Kuantitatif, Kualitatif Dan R\&D, (April 1952), 80.

Surata, A., \& Andrianto, T. T. (2001). Atasi konflik etnis. Jurnal Mitra Ekonomi Dan Manajemen Bisnis, 2(2), 212-224.

Undang-Undang_No_38.(2004). UndangUndang_No_38_TAHUN_2004 Jalan.

https://padang.tribunnews.com/2020/02/13 /trase-jalan-tol-padang-pekanbaru-disicincin-berubahgubernur-sumbarirwan-prayitno-ungkap-alasannya, 